\title{
ASPEK HUKUM TERHADAP TRANSAKSI PINJAMAN ONLINE
}

\author{
Wahyuni \\ Dosen Fakultas Syariah Institut Agama Islam Negeri Palu \\ wahyuni@iainpalu.ac.id
}

\begin{abstract}
Online loans are currently being discussed a lot, especially regarding the legality underlying. Where there is no clarity regarding the transaction mechanism and the legal consequences of the achievements made by both parties, and also not a few who end it through criminal law. In this regard, the authors would like to emphasize several legal aspects of this online loan transaction by conducting a normative-empirical legal analysis, using several approaches, including the approach to related laws and regulations, a case study approach related to online loan cases and a comparative approach or comparison to compare loan transactions made online and loan transactions made offline. Because the transaction mechanism is carried out online, this agreement cannot be separated from the principles adopted in civil law as well as the conditions for the validity of an agreement, so that even though online loan transactions are carried out online, they must be subject to applicable laws and regulations. and carry out the process of validating data and information for each party so that in the event of a default by one of the parties it can be resolved without harming one of the parties in the transaction.
\end{abstract}

Keywords: Financial Technology; Legal Perspective; Online loans

\begin{abstract}
Abstrak
Pinjaman Online saat ini sedang banyak diperbincangan terutama mengenai payung hukum yang mendasarinya. Dimana belum ada kejelasan terkait bagaimana mekanisme transaksinya serta bagaimana akibat hukum dari prestasi yang dilakukan oleh kedua belah pihak, dan pula tidak sedikit yang mengakhirinya melalui jalur hukum pidana. Berkaitan dengan hal tersebut, maka penulis ingin menegaskan beberapa aspek hukum terhadap transaksi pinjaman online ini dengan melakukan analisis secara hukum normatif-empiris, dengan menggunakan beberapa pendekatan, antara lain pendekatan peraturan perundang-undangan terkait, pendekatan studi kasus yang berkaitan dengan kasus pinjaman online dan pendekatan komparasi atau perbandingan untuk membandingkan transaksi pinjaman yang dilakukan secara online dan transaksi pinjaman yang dilakukan secara offline. Oleh karena mekanisme transaksi yang dijalankan secara online, maka perjanjian ini tidak terlepas dari prinsip-prinsip yang dianut dalam hukum keperdataan serta yang menjadi syarat sahnya suatu perjanjian, sehingga transaksi pinjaman online tersebut sekalipun dilakukan secara online, namun harus tunduk pada perundang-undangan yang berlaku serta melakukan proses validasi data dan informasi masing-masing pihak sehingga ketika terjadi wanprestasi oleh salah satu pihak dapat diselesaikan tanpa merugikan salah satu pihak dalam transaksi tersebut.
\end{abstract}

Kata kunci: Aspek Hukum; Teknologi Finansial; Pinjaman Online

TADAYUN: 


\section{A. PENDAHULUAN}

Perkembangan teknologi informasi saat ini tidak dapat dipungkiri telah banyak mempengaruhi tatanan hidup masyarakat, termasuk dalam rangka memenuhi kebutuhan hidupnya. Banyak hal yang dapat dilakukan saat ini hanya dengan menggunakan alat komunikasi berbasis teknologi informasi diantaranya adalah penyediaan aplikasi layanan publik. Salah satu aplikasi yang banyak tersebar saat ini adalah aplikasi pinjaman online. Aplikasi ini telah menghampiri sejuta penduduk di Indonesia dengan tawaran yang memudahkan sistem transaksi pinjaman sejumlah uang dimana sistem sebelumnya dirasakan banyak menyita waktu serta kurang efisien. Hal tersebut dibuktikan dengan beberapa testimoni sejumlah pengguna jasa layanan transaksi pinjaman online tersebut.

Namun, dibalik kemudahan yang ditawarkan oleh aplikasi transaksi pinjaman online tersebut tanpa disadari banyak orang yang sebenarnya telah terjebak dalam mekanisme perjanjian tersebut. Mulai dari ketidakjelasan penyelenggara layanan pinjaman online, mekanisme yang tidak mengindahkan prinsip-prinsip dalam hukum perjanjian serta penyelesaian masalah yang tidak sesuai dengan ketentuan perundangundangan yang berlaku, belum lagi ditambah dengan sisi kelemahan perjanjian yang ditawarkan. Kompleksnya permasalahan tersebut, saat ini tidak sedikit yang memberikan perhatian tentang bagaimana sebaiknya penyelenggaraan pelayanan jasa transaksi pinjaman online tersebut, baik dari aspek hukumnya maupun aspek pertumbuhan perekonomian nasional.

Transaksi pinjaman online merupakan istilah yang umum digunakan oleh masyarakat, namun sebenarnya telah dibakukan dalam Peraturan Otoritas Jasa Keuangan Nomor 77/POJK.01/2016 tentang Layanan Pinjam Meminjam Uang Berbasis Teknologi Informasi. Disebutkan bahwa layanan pinjam meminjam uang berbasis teknologi informasi adalah penyelenggaraan layanan jasa keuangan untuk mempertemukan pemberi pinjaman dengan penerima pinjaman dalam rangka melakukan perjanjian pinjam meminjam dalam mata uang rupiah secara langsung melalui sistem elektronik dengan menggunakan jaringan internet. Adanya aplikasi layanan pinjaman online ini oleh Otoritas Jasa Keuangan telah menetapkan beberapa ketentuan, antara lain: 
1. Penyelenggara layanan pinjaman online ialah usaha berbadan hukum di Indonesia yang sebagai penyedia, pengelola, dan pengoprasian pelayanan pinjaman yang berbasis akan teknologi infornasi;

2. Batas maksimun jumlah pinjaman online yakni senilai Rp.2.000.000.000 (dua miliar rupiah) dan dapat ditinjau terhadap batas maksimum tersebut oleh Otoritas Jasa Keuangan (OJK);

3. Penyelenggara pinjaman online harus terdaftar dan menadapatkan izin dari Otoritas Jasa Keuangan (OJK).

Ketentuan tersebut, dapat dinilai hanya bersifat administratif terhadap layanan transaksi pinjaman online, tidak memiliki unsur-unsur dalam mekanisme menyelesaikan masalah, padahal masalah yang muncul saat ini bahwa bagaimana bisa dengan suatu aplikasi berani meminjamkan sejumlah uang tanpa menyeleksi orangorang yang akan berutang ditambah dengan kondisi ekonomi yang tidak menentu saat ini serta tindak kriminalitas yang cukup tinggi, atau dengan kata lain mempercayai orang yang akan meminjam uang tanpa ada tahapan BI Checking.

Transaksi pinjaman online ini telah mengikis prinsip-prinsip yang ada pada hukum perjanjian ${ }^{1}$, dimana dalam suatu perjanjian harus berasaskan konsensualisme yakni suatu perjanjian mengikat kedua belah pihak yang bersepakat mengikatkan dirinya dalam suatu perjanjian, dan dengan transaksi pinjaman online tersebut, bagaimana kedua belah pihak menyatakan sepakat dalam perjanjian, sedangkan masing-masing pihak tidak bertemu, pengguna layanan sebagai orang yang berutang hanya melakukan apa yang diperintahkan aplikasi tersebut. Kita tidak akan tahu siapa yang menggunakan aplikasi tersebut dengan kedok kondisi kelalaian pihak yang menggunakan aplikasi tersebut dan dikemudian hari ternyata menimbulkan masalah.

Kemudian pada asas kebebasan berkontrak, asas ini menekankan pada kebebasan antara menggunakan ataupun tidak menggunakan perjanjian serta kebebasan melakukan perjanjian bersama siapapun. Kebebasan dalam aspek apapun baik penentuan isi dari kontrak, seperti apa kemudian praktiknya kedepan dan syarat dalam perjanjiannya serta bentuk dari perjanjian. Kalau kita melihat pada praktik

\footnotetext{
${ }^{1}$ Salim H.S, Hukum Kontrak: Teori Dan Teknik Penyusunan Kontrak, 14th ed. (Jakarta: Sinar Grafika, 2019), 9.
} 
transaksi pinjaman online ini, maka asas kebebasan berkontrak ini nyaris tidak sempurna dijalankan dalam perjanjian tersebut. Bebas membuat perjanjian, perjanjian secara umum oleh penyedia jasa layanan dirumuskan oleh pihak yang memberi pinjaman. Dan pengguna jasa tersebut akan menandatangani apa yang disodorkan kepadanya. Dan pada kenyataannya ketika ada niat meminjam uang apalagi dalam kondisi terdesak seseorang hanya langsung menandatangani perjanjian tersebut saja. Atau jika dalam bentuk aplikasi, seseorang langsung saja mengklik OK pada pilihan menunya.

Asas kepastian hukum dalam hukum perjanjian juga harus dipenuhi dalam transaksi pinjaman online. Memang perjanjian yang disepakati oleh kedua belah pihak berlaku bagi pihak-pihak yang membuatnya. Namun apakah perjanjian dalam transaksi pinjaman online itu tidak menciderai hukum bagi para pihak. Disini harus ada campur tangan pemerintah. Sampai saat ini pemerintah belum sama sekali ikut andil dalam perjanjian online ini.

Kemudian asas itikad baik dalam hukum perjanjian dilihat dalam konsep transaksi pinjaman online. Asas ini dapat saja dilunturkan nilai substansinya karena proses yang dijalankan secara online. Seseorang yang misalnya sudah diberikan pinjaman tiba-tiba tidak memiliki itikad baik untuk menjalankan kewajibannya dengan cara yang mudah saja seperti dengan memblokir semua nomor kontak yang melakukan penagihan kepadanya. Setelah si peminjam tidak dapat dihubungi maka pemberi jasa layanan transaksi pinjaman online bisa melakukan apa dengan kondisi demikian. Melacak nomor kontak sudah tidak bisa dilakukan dan akhirnya melakukan sebuah upaya hukum baik itu gugatan perdata ataupun membuat laporan pidana. Kemudian asas itikad baik ini juga sulit untuk diaplikasikan melalui media online sehubungan dengan tidak adanya barang jaminan dari pihak peminjam.

Asas itikad baik juga berhubungan dengan asas kepribadian. Asas kepribadian merupakan salah satu prinsip hukum perjanjian dalam hal unsur kecakapan seseorang dalam bertanggungjawab terhadap isi perjanjian yang telah disepakati. Dengan sistem pinjaman online ini, terhadap asas kepribadian maka yang harusnya dilakukan lebih dulu adalah dengan melakukan BI Checking. Namun yang terjadi pada banyak aplikasi pinjaman online tersebut tidak melakukan BI Checking karena memang prinsip pada 
pinjaman online ini adalah memudahkan pada sistem transaksi pinjamannya. Dari gambaran kasus tersebut, maka dampaknya tidak sedikit para pengguna jasa pinjaman online tersebut tidak memenuhi kewajibannya dan berbuntut pada persoalan perdata termasuk pidana.

Sekalipun perjanjian ini dijalankan dengan mekanisme berbasis teknologi informasi namun tidak bisa juga mengeyampingkan aspek hukum perjanjian yang seharusnya ada dalam setiap perjanjian meskipun perjanjian itu dijalankan dengan mekanisme berbeda atau menggunakan teknologi informasi.

Metode penelitian yang digunakan pada tulisan ini adalah metode penelitian hukum normatif-empiris yaitu dengan melihat beberapa kasus yang terjadi pada masyarakat sebagai pengguna aplikasi pinjaman online kemudian mengkajinya sesuai dengan peraturan perundang-undangan yang berlaku serta teori-teori hukum yang berkaitan dengan hukum perjanjian. Tulisan ini juga merujuk pada bahan kepustakaan seperti buku, jurnal dan media online yang dapat dipertanggungjawabkan dan menyimpulkannya secara deskriptif analitis.

\section{B. HASIL DAN PEMBAHASAN}

Transaksi pinjaman online diwadahi dalam bentuk layanan jasa keuangan yang mempertemukan pemberi pinjaman dengan calon penerima pinjaman dan atau penerima pinjaman secara langsung melalui media elektronik. Layanan financial berupa transaksi peminjaman online ini dinaungi oleh OJK (Otoritas Jasa Keuangan) layaknya penyelenggara layanan financial lainnya seperti lembaga keuangan Bank, pergadaian dan sebagainya. Peran OJK terhadap pelayanan financial tekhnologi dalam aspek Peer to peer lending mencakup aspek pemeriksa, aspek pengatur, aspek pengawas serta termasuk menyelidiki seperti yang tercantum dalam aturan UndangUndang Nomor 21 Tahun 2011 mengenai Otoritas Jasa Keuangan.

Terkait dengan aspek pengaturan, maka oleh OJK mempersyaratkan kepada setiap layanan transaksi pinjaman online lebih dulu harus memiliki status kedudukan hukum yang jelas, kedudukan hukum dimaksud untuk memberikan kepastian hukum terhadap pengguna layanan jasa keuangan yakni penerima pinjaman dan pemberi pinjaman yang berupa transaksi pinjaman online. Adapun status hukum dari 
penyelenggara layanan transaksi pinjaman online ini adalah harus berbadan hukum Indonesia yang berperan dalam penyediaan, pengelolaan dan operasional pelayanan pinjam meminjam secara online. Dengan demikian maka dapat dipahami bahwa pihakpihak (Pemberi pinjaman dan Penerima Pinjaman) dalam transaksi pinjaman online ini dipertemukan lewat penyelenggara layanan pinjam meminjam uang berbasis teknologi informasi.

Pihak dalam transaksi pinjaman online terdiri dari penerima pinjaman dan pemberi pinjaman. Penerima pinjaman meliputi orang perseorangan, badan hukum dan bisa juga badan usaha yang mempunyai piutang lewat layanan transaksi pinjaman online sedangkan pemberi pinjaman merupakan orang perseorangan, badan hukum dan atau badan usaha yang mempunyai piutang melalui transaksi pinjaman online. Kedua pihak tersebut kedudukannya sama sesuai dengan ketentuan hukum perdata Indonesia. ${ }^{2}$

Direksi dan Komisaris pada penyelenggara layanan jasa transaksi pinjaman online merujuk pada Undang-Undang Nomor 40 Tahun 2007 tentang Perseroan Terbatas, dan jika penyelenggaranya merupakan badan hukum koperasi, maka kepengurusannya tunduk pada Undang-Undang Nomor 25 Tahun 1992 tentang Perkoperasian.

Adapun dokumen elektronik pada setiap sistem informasi elektronik transaksi pinjaman online baik yang dibuat, diteruskan, dikirimkan, diterima, dan atau disimpan dalam bentuk analog, digital, elektromagnetik, optikan dan sejenisnya yang dapat dilihat, ditampilkan dan atau didengar melalui alat sistem elektronik tunduk pada Undang-Undang Nomor 11 Tahun 2008 tentang Informasi dan Transaksi Elektronik. Begitupun juga yang berlaku pada sertifikat elektronik dan tanda tangan elektronik.

Terkait dengan sertifikat elektronik pada transaksi pinjaman online yang dimaksud adalah sertifikat yang dikeluarkan oleh penyelenggara sertifikat elektronik yang bertugas dalam memberikan termasuk mengaudit sertifikat-sertifikat yang

\footnotetext{
${ }^{2}$ Ratna Hartanto and Juliyani Purnama Ramli, "Hubungan Hukum Para Pihak Dalam Peer To Peer Lending," Jurnal Hukum Ius Quia Iustum 25, no. 2 (2018): 320-38, https://doi.org/10.20885/iustum.vol25.iss2.art6.
} 
terdaftar di OJK. Sertifikat elektronik memuat tanda tangan elektronik dan identitas para pihak untuk menunjukkan status pihak-pihak dalam transaksi pinjaman online.

Dokumen elektronik pada transaksi pinjaman online sangat penting bersamaan halnya pada perjanjian offline. Jika kedua belah pihak telah sepakat mengadakan perjanjian, maka kedua pihak tersebut bertanda tangan dengan disaksikan oleh beberapa orang sebagai saksi. Namun untuk perjanjian pada transaksi pinjaman online dimuat dalam dokumen elektronik termasuk sertifikat elektronik yang menjadi pegangan hukum masing-masing pihak pemberi dan penerima pinjaman serta penyelenggara layanan pinjaman uang berbasis teknologi informasi.

Kegiatan usaha transaksi pinjaman online oleh penyelenggara layanan pinjaman online melakukan penyediaan, mengelola serta mengoperasikan aplikasi layanan transaksi online tersebut dari pihak pemberi pinjaman ke penerima pinjaman dengan sumber dana berasal dari pemberi pinjaman, sehingga untuk si pemberi pinjaman lebih dulu melakukan kerjasama sebelum layanan jasa pengelolaan transaksi pinjaman online ini dipublikasikan pada para calon penerima pinjaman.

Penyelenggara transaksi pinjaman online harus mematuhi ketetapan pembatasan jumlah maksimal pinjaman yang dapat diberikan. Ketetapan tersebut diatur dalam Pasal 6 Peraturan Otoritas Jasa Keuangan Nomor 77/POJK.01/2016 tentang Layanan Pinjam Meminjam Uang Berbasis Teknologi Informasi, dengan penegasan bahwa jumlah maksimal pinjaman melalui transaksi pinjaman online adalah tidak lebih dari Rp. 2.000.000.000,00 (dua miliar rupiah) sebagaimana ditegaskan dalam Pasal 2 ayat (2) Peraturan Otoritas Jasa Keuangan Nomor 77/POJK.01/2016 tentang Layanan Pinjam Meminjam Uang Berbasis Teknologi Informasi. Selain itu, penyelenggara jasa pinjaman online juga harus terdaftar dan mendapatkan izin dari OJK.

Tata cara pendaftaran serta cara memperoleh izin dari OJK mensyaratkan ketentuan-ketentuan yang bersifat khusus disamping syarat umum sebagaimana diatur dalam Undang-Undang Nomor 40 Tahun 2007 tentang Perseroan Terbatas, adapun syarat khusus untuk mendapatkan izin penyelenggaraan jasa layanan pinjaman berbasis teknologi informasi, yaitu surat penyataan bermaterai yang menerangkan:

1. Dana sebagai modal pinjaman merupakan kepemilikan sempurna; 
2. Dana modal bukan dari hasil kejahatan finansial dan atau praktik money laundering;

3. Belum pernah memiliki riwayat kredit macet;

4. Belum pernah dikenai hukuman atas tindak pidana berkaitan dengan finansial dalam 5 (lima) tahun terakhir;

5. Belum pernah dikenai hukuman atas tindak pidana berkaitan dengan kejahatan lainnya dalam 5 (lima) tahun terakhir;

6. Belum pernah mendapatkan putusan pengadilan dalam 5 (lima) tahun terakhir terkait pernyataan bangkrut atau menjadi penyebab bangkrutnya suatu perusahaan; dan

7. Belum pernah dalam 5 (lima) tahun terakhir bertindak sebagai pimpinan kepemilikan saham, atau komisaris dalam perusahaan financial yang melakukan pelanggaran sehingga berakibat pencabutan perizinan usaha.

Ketujuh syarat tersebut juga berlaku bagi badan hukum yang terdaftar dan akan memperoleh izin penyelenggara jasa pinjaman online dari OJK. Pemberi pinjaman online sebagai pengguna jasa penyelenggara pinjaman online dapat berasal dari pemberi pinjaman luar negeri dan tetap tunduk pada ketentuan peraturan perundangundangan Indonesia. Antara penyelenggara dan pemberi pinjaman online perlu membuat perjanjian atau kesepakatan tertulis lebih dulu terkait dengan kerjasama yang mereka buat, terutama mengenai suku bunga yang juga patut mempertimbangkan aspek kewajaran serta perkembangan perekonomian nasional.

Model perjanjian pinjaman online dibagi atas perjanjian antara penyelenggara dengan pemberi pinjaman dan perjanjian antara pemberi pinjaman dengan penerima pinjaman. Perjanjian penyelenggara pinjaman dengan pemberi pinjaman dituangkan dalam dokumen elektronik yang sekurang-kurangnya memuat nomor perjanjian, tanggal perjanjian, identitas para pihak, hak dan kewajiban para pihak, jumlah pinjaman, suku bunga pinjaman, komisi, jangka waktu, biaya-biaya diluar jumlah pinjaman, denda serta cara penutupan usaha.

Penyelenggarai pinjaman online diwajibkan memberikan informasi pada pemberi modal yang meliputi informasi mengenai total kebutuhan modal yang akan 
diberikan pada peminjam, tujuan dari peminjaman dana, besarani bunga serta waktu pinjaman. Penjelasan yang dikecualikan untuk diakses oleh si pemberi pinjaman adalah terkait identitas para penerima pinjaman.

Bentuk perjanjian kedua adalah perjanjian antara pemberi pinjaman dan penerima pinjaman. Perjanjian keduanya juga dituangkan dalam dokumen elektronik yang memuat hal yang hampir sama dengan perjanjian antara penyelenggara pinjaman online dengan pemberi pinjaman. Penyelenggara pinjaman online menyediakan akses informasi terkait posisi pinjaman yang diterima si penerima pinjaman. Untuk penyelenggara pinjaman online dilarang memberi akses informasi terkait identitas si pemberi pinjaman kepada penerima pinjaman.

Transaksi pinjaman online juga perlu melakukan mitigasi risiko sesuai ketentuan yang ditetapkan oleh OJK. Penyelenggara harus memiliki pusat data dan pusat pemulihan bencana yang bertempat di Indonesia yang mampu memenuhi seluruh standar yang telah ditetapkan. Penyelenggara diwajibkan:

1. Menjaga kerahasiaan dan kelengkapan informasi pribadi dan informasi financial pengguna sejak dikumpulkan hingga nantinya dihapuskan saat telah berakhir;

2. Menetapkan penyediaan otentikasi, verifikasi serta validasi untuk menghindari penolakan pengaksesan, pemrosesan dan penegakan informasi pribadi dan informasi financial yang dikelola;

3. Memastikan bahwa pengumpulan, pengungkapan, dan penggunaan informasi pribadi serta informasi financial pengguna layanan diperoleh dengan didasarkan pada persetujuan pengguna, kecuali terdapat ketentuan lain melalui peraturan perundang-undangn;

4. Tersedianya sarana komunikasi lainnya, bukan hanya melalui satu media aplikasi penyelenggara saja. Agar pelayanan pada pengguna dapat konteniu melalui media informasi lainnya; dan

5. Bersikap terbuka jika terjadi kesalahan serta kegagalan dalam menyimpan kerahasiaan data informasi pengguna yang dikelola, dengan memberikan pemberitahuan secara tertulis pada pengguna layanan. 
Penyelenggara layanan tekhnologi financial dalam aspek pinjaman merupakan pihak utama yang berperan penting dalam transaksi pinjaman online. Ruang kendalinya diamati oleh OJK dan jika tidak sesuai dengan ketentuan operasional sebagaimana ditetapkan dalam peraturan OJK, maka izin penyelenggaraannya dapat dicabut serta berkonsekuensi terhadap sanksi hukum yang berlaku. Oleh OJK mewajibkan kepada penyelenggara untuk melakukan rekam jejak audit terhadap seluruh kegiatannya dalam transaksi pinjaman online. Sehingga seluruh kegiatannya perlu ditunjang dengan perangkat yang mendukung mekanisme rekam jejak audit tersebut. Rekam jejak audit ini sangat diperlukan dalam hal keperluan pengawasan, penegakan hukum, penyelesaian sengketa, verifikasi, pengujian serta pemeriksaan lainnya.

Selain itu, diwajibkan pula bagi penyelenggara jasa pinjaman online ini untuk memiliki sistem pengamanan yang mewadahi semua komponen sistem informasi berbasis teknologi informasi dalam hal menghindari terjadinya gangguan, kegagalan sistem serta kerugian. Dalam sistem pengamanan tersebut mencakup semua prosedur, sistem pencegahan termasuk penanggulangan terhadap ancaman dan serangan yang dapat menimbulkan gangguan, kegagalan sistem serta kerugian tersebut.

Dari semua aspek hukum yang diwajibkan kepada penyelenggara tersebut, yang paling urgen adalah aspek edukasi serta perlindungan terhadap pengguna layanan pinjaman online. Edukasi yang paling penting menurut penulis adalah edukasi teruntuk si calon pengguna aplikasi layanan pinjaman online tersebut. Karena melihat kebanyakan iklan layanan pinjaman online yang dipublikasikan oleh penyelenggara kepada publik yang nampak hanyalah kemudahan-kemudahan yang ditawarkan untuk mendapatkan pinjaman. Sehingga dikemudian hari banyak pihak yang terjebak pada kondisi yang tidak menyanggupi ketentuan layanan pinjaman online tersebut.

Berikut salah satu bedah kasus yang akan penulis ingin sampaikan kepada pihak-pihak yang akan menggunakan aplikasi pinjaman online tersebut sebagai suatu bentuk edukasi mengenai pemahaman transaksi pinjaman online. Agar dikemudian hari terutama bagi si pengguna layanan tidak terburu-buru mengambil keputusan menggunakan aplikasi pinjaman online apalagi pada saat menggunakan aplikasi tersebut si calon pengguna dituntun dengan hanya klik-klik menu aplikasi, tanpa jedah 
waktu memberikan pertanyaan yang kurang dimengerti kepada penyelenggara transaksi pinjaman online.

Seseorang yang awalnya hanya cukup bermodalkan HP (Handphone) serta data internet kemudian ditawari oleh iklan pinjaman online dengan konten cara mendaftar dan sistem transaksi yang mudah tentu sangat menggoda banyak kalangan. Penyelenggara pinjaman online menyediakan aplikasi pinjaman online kemudian menuntun si calon pengguna untuk mendownload dan install serta memasukan datadata dengan cara yang sangat mudah. Kemudian si calon pengguna memasukkan sejumlah uang yang dibutuhkan misalnya senilai 2 juta rupiah dan dalam waktu yang singkat dana tersebut di transfer ke rekening pengguna.

Tetapi dari cara yang mudah tersebut, pada kenyataannya jumlah uang yang kita ajukan tidak sama dengan sejumlah dana pinjaman yang diajukan, karena dipotong dengan biaya administrasi dengan persentase 10-16\%, sehingga dari dana pengajuan pinjaman 2 juta rupiah yang akan ditransfer ke rekening pengguna hanya sekitar 1.8 juta rupiah. Dari sini kita sudah kehilangan uang 200 ribu rupiah yang mana hal ini memang bisa saja dimaklumi karena berlaku pada semua perusahaan dibidang layanan jasa keuangan. Tetapi perlu diketahui bagi si pengguna transaksi pinjaman online bahwa titik mula masalahnya baru akan dirasakan setelah dana itu ditransfer.

Dana pinjaman sejumlah 2 juta rupiah akan dikredit selama 6 bulan dengan biaya per bulannya adalah 640 ribu rupiah. Dari sini tentu kita juga harus sudah berhitung tentang berapa Bunga dengan pinjaman senilai 2 juta tersebut. Jika uang 640 ribu rupiah dibayarkan selama 6 bulan maka jumlah keseluruhan yang akan dikembalikan adalah sejumlah 3,8 juta rupiah. Dan tentunya dana awal yang ditransfer adalah hanya 1,8 juta. Sehingga dengan begitu bahwa pengembalian tentu lebih besar dari jumlah pinjaman.

Suku bunga pinjaman online di Indonesia berkisar rata-rata 0,8\%, dengan rincian bulanan sebesar $24 \%$ perbulan atau $288 \%$ pertahun. Ilustrasi diatas dimisalkan hanya menggunakan bunga yang lebih rendah yakni 270\% pertahun, artinya jumlah yang dibayarkan perbulannya bisa lebih dari 640 ribu rupiah.

Khusus pada tahun 2021, akumulasi dari pinjaman online untuk pengguna yang berasal dari Indonesia menembus jumlah uang 200 trilyun. Oleh karena itu, OJK dalam 
hal ini sebagai lembaga yang berwenang mengawasi penyelenggaraan transaksi pinjaman online mulai dan harus serius mengawasi operasional transaksi pinjaman online yang sudah lama ini beredar di masyarakat yang dimana penggunanya adalah sebagian besar yang hanya fokus mendapatkan uang 1,8 juta rupiah tanpa tahu ketentuan perhitungan bunga dari penyelenggara pinjaman online.

OJK perlu membuat regulasi terkait batas maksimal bunga dari penyelenggara pinjaman online ${ }^{3}$ tersebut, meskipun memang dalam transaksi tersebut berhubungan dengan hukum perjanjian, namun jika sudah terjadi banyak kasus wanprestasi, maka OJK sebagai perwakilan negara harus hadir menengahi masalah hukum perseorangan tersebut. Ini masalah yang benar-benar serius ditengah himpitan ekonomi masyarakat yang mulai melemah yang salah satunya diakibatkan pandemi covid-19 yang tidak kunjung selesai. OJK perlu mensosialisasikan transaksi pinjaman online ini sebagai bentuk edukasi dan literasi keuangan kepada masyarakat, jangan menjerat masyarakat terjebak pada keadaan yang tidak berkepastian seperti saat ini. OJK harus perketat pengawasan transaksi pinjaman online, karena juga terdapat beberapa aplikasi pinjaman online yang beredar dimasyarakat berwatak rentenir dan bisa jadi pelegalannya tidak dalam pengawasan OJK ataupun OJK belum mampu mengendalikan sejumlah aplikasi pinjaman online yang beredar di masyarakat.

Sejauh ini telah dibentuk Satuan Petugas Waspada Investasi (SWI). SWI ini bertugas mengawasi Fintech Lending atau pinjaman online yang terdaftar di OJK termasuk menggencarkan edukasi ke masyarakat untuk tidak menggunakan pinjaman online yang ilegal dan hanya memanfaatkan pinjaman online yang terdaftar secara resmi di OJK. ${ }^{4}$

Pembentukan SWI ini merupakan bagian penegakan hukum terhadap pelaku aplikasi pinjaman online ilegal. SWI beranggotakan 12 kementerian dan lembaga yang

\footnotetext{
${ }^{3}$ Antoni Tjandra, "Kekosongan Norma Penentuan Bunga Pinjaman Financial Technology Peer To Peer Lending," Jurnal Hukum Bisnis Bonum Commune 3, no. 1 (2020): 90-103, https://doi.org/10.30996/jhbbc.v3i1.3077.

${ }^{4}$ Mochamad Januar Rizki, Penegakan Hukum Pelaku Pinjol Ilegal Diperlukan Sebagai Efek Jera. https://www.hukumonline.com, diakses pada tanggal 14 Juni 2021
} 
melaksanakan pengupayahan demi pencegahan kejahatan financial melalui polisi cyber yang akan mengamankan pinjaman illegal dalam ruang siber.

Dengan beberapan uraian diatas, maka secara garis besar aspek hukum terhadap transaksi pinjaman online ini perlu memperhatikan hal-hal sebagai berikut:

1. Penyelenggara pinjaman online wajib memiliki izin resmi dari OJK;

2. Identitas seperti pengurus serta alamat kantor penyelenggara pinjaman online harus jelas;

3. Pemberian pinjaman sesuai dengan prosedur yang tidak bertentangan dengan ketentuan perundang-undangan yang berlaku. Dan patut menduga atas pemberian pinjaman dengan cara yang sangat mudah;

4. Memperhatikan dan memperhitungkan dengan teliti atas penjelasan bunga pinjaman serta pengenaan denda keterlambatan;

5. Batasan waktu penagihan;

6. Perizinan pengaksesan keseluruh informasi pada ponsel pengguna jasa aplikasi pinjaman online;

7. Ancaman teror kekerasan kepada pengguna jasa aplikasi pinjaman online;

8. Penghinaaan serta pencemaran nama baik pengguna jasa aplikasi pinjaman online;

9. Menyebarkan foto/video pribadi pengguna jasa aplikasi pinjaman online;

10. Tidak tersedianya layanan pengaduan bagi pengguna jasa pinjaman online.

SWI saat ini sangat berperan dalam mendorong penegakan hukum kepada para pelaku pinjaman online ilegal diantaranya dengan pemblokiran situs dan aplikasi serta bekerjasama dengan pihak OJK, PPATK, Perbankan dan Dittipisiber Bareskrim Polri untuk melakukan analisis dan penyelidikan tentang transaksi pinjaman online ini.

\section{KESIMPULAN}

Aspek hukum terhadap transaksi pinjaman online ini melibatkan 3 (tiga) bagian hukum, yaitu hukum perdata, hukum administrasi dan hukum pidana. Pada aspek hukum perdata, antara pengguna dan penyelenggara pinjaman online wajib memperhatikan isi perjanjian atau kontrak kesepakatannya, sebab perjanjian yang 
telah disepakati kedua belah pihak akan menjadi undang-undang bagi mereka yang membuatnya. Konsekuensi dari perikatan perdata adalah wanprestasi. Kemudian pada aspek hukum administrasi yang menyangkut tentang sistem perizinan bagi penyelenggara aplikasi pinjaman online, penegakan hukum administrasi dan berkaitan dengan fungsi OJK dalam mengawasi operasional pinjaman online yang terdaftar secara resmi di OJK. Dan pada aspek hukum pidananya adalah penegakan hukum pidana seperti melakukan proses hukum terhadap penyedia jasa online yang dilakukan secara ilegal dan merugikan masyarakat yang terjebak dalam pinjaman online ilegal.

Saran kedepannya OJK harus mensosialisasikan penyelenggaraan pinjaman online ini kepada masyarakat dengan cara mengedukasi masyarakat agar lebih berhatihati terlebih pada penyedia jasa pinjaman keuangan online yang ilegal. Serta perlu mengintensifkan kontrol pengawasan terhadap penyelenggara pinjaman online dan membangun kerjasama kepada pihak-pihak terkait dalam rangka peningkatan pengawasan terhadap transaksi pinjaman online.

\section{REFERENSI}

H.S, S. (2019). Hukum Kontrak: Teori dan Teknik Penyusunan Kontrak (14th ed.). Jakarta: Sinar Grafika.

Hartanto, R., \& Ramli, J. P. (2018). Hubungan Hukum Para Pihak Dalam Peer To Peer Lending. Jurnal Hukum Ius Quia Iustum, 25(2), 320-338. https://doi.org/10.20885/iustum.vol25.iss2.art6

Mochamad Januar Rizki, Penegakan Hukum Pelaku Pinjol Ilegal Diperlukan Sebagai Efek Jera. https://www.hukumonline.com

Otoritas Jasa Keuangan. (2016). Peraturan Otoritas Jasa Keuangan Nomor: 77 /POJK.01/2016 Tentang Layanan Pinjam Meminjam Uang Berbasis Teknologi Informasi. In Otoritas Jasa Keuangan (pp. 1-29). https://www.ojk.go.id/id/regulasi/otoritas-jasa-keuangan/peraturanojk/Documents/Pages/POJK-Nomor-77-POJK.01-2016/SAL - POJK Fintech.pdf

Soesilo. (2008). Kitab Undang-Undang Hukum Perdata - Burgerlijk Wetboek. Rhedbook Publisher.

Tjandra, A. (2020). Kekosongan Norma Penentuan Bunga Pinjaman Financial 
Technology Peer To Peer Lending. Jurnal Hukum Bisnis Bonum Commune, 3(1), 90103. https://doi.org/10.30996/jhbbc.v3i1.3077 